\title{
The Impact of the Skills Gap on the Recruitment of MIS Graduates
}

\author{
Andrew Aken \\ Department of Management \\ College of Business and Administration \\ Southern Illinois University \\ Carbondale, IL \\ 1-618-434-4501 \\ ajaken@cba.siu.edu
}

\author{
Dr. Michael D. Michalisin \\ Department of Management \\ College of Business and Administration \\ Southern Illinois University \\ Carbondale, IL \\ 1-618-453-7884 \\ drmike@cba.siu.edu
}

\begin{abstract}
Enrollment in MIS degree programs has been dropping significantly since 2001. Some of the reasons for this decline include the perceived lack of jobs for MIS graduates, confusion over the variety of computing degree programs, disinterest in MIS careers, and MIS programs which fail to prepare students adequately for careers in MIS. This paper looks at each of these potential causes for the enrollment decline and offers suggestions to reverse this trend. Given the lack of material support for the first three potential causes of the decline in enrollment, the bulk of this research is devoted to investigating the deficiencies of the MIS program from the employer's perspective.

We will conduct a survey which will identify which skills MIS graduates are lacking from the employer's point of view and what impact this skills gap has on the recruitment practices of the employers. Our belief is that once employers begin actively recruiting for MIS graduates, the misperceptions of the job prospects for MIS graduates by potential students will likewise diminish and enrollment in the programs which respond to industries' needs will subsequently rebound.
\end{abstract}

\section{Categories and Subject Descriptors}

K.3.2 Computer and Information Science Education Curriculum, K.6.1 Project and People Management - Staffing

\section{General Terms}

Management, Human Factors, Measurement

\section{Keywords}

MIS workforce, skills gap, job skills, IT skills, MIS personnel

\section{INTRODUCTION}

A crisis has been facing business schools offering MIS degrees for the past several years in the United States. Declining enrollments in the program have had many schools looking into redesigning or eliminating their MIS programs. Although the

Permission to make digital or hard copies of all or part of this work for personal or classroom use is granted without fee provided that copies are not made or distributed for profit or commercial advantage and that copies bear this notice and the full citation on the first page. To copy otherwise, or republish, to post on servers or to redistribute to lists, requires prior specific permission and/or a fee.

SIGMIS-CPR'07, April 19-21, 2007, St. Louis, Missouri, USA.

Copyright 2007 ACM 978-1-59593-641-7/07/0004...\$5.00. word “crisis” may seem alarmist and overly melodramatic, it is certainly fitting in this context. The declining enrollment in MIS programs not only negatively impacts those colleges offering these programs, but it also has a dramatic impact on industry as well. If the projections for growth in this sector are even remotely accurate, we will face a significant shortfall in qualified applicants for positions normally filled by MIS graduates. The only recourse for industry would be to outsource these positions which will further depress the future enrollment in MIS programs.

There are many potential causes for this decline in enrollment including the perceived lack of jobs for MIS graduates, confusion over the variety of computing degree programs, disinterest in MIS careers, and poorly implemented MIS programs. This research will attempt to address each of these possible sources of declining enrollments.

\subsection{The Jobs "Crisis"}

Since the dot-com bust in 2001, there has been a general perception of reduced MIS jobs and that those that do exist are being outsourced to overseas firms. Although outsourcing or "offshoring" of IT jobs has been increasing steadily over the past decade, the IT job market in the US has actually increased since the days of the dot-com boom (especially in MIS). The US Department of Labor predicts that many IT occupations will actually be among the fastest growing professions for at least the next decade.

The US Bureau of Labor Statistics' reports from 2005 show the following job growth from 2000 through 2005 in computing professions:

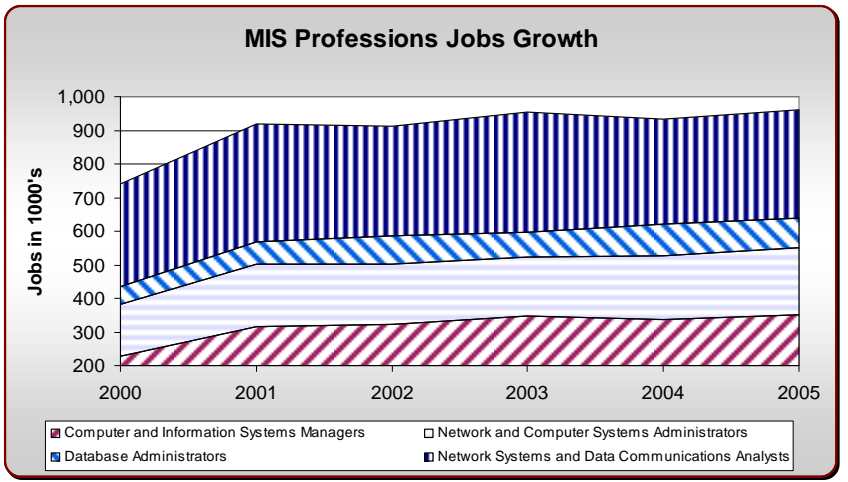




\begin{tabular}{|c|c|c|c|c|c|c|c|}
\hline \multirow[b]{2}{*}{ Occupations } & \multicolumn{6}{|c|}{ Jobs - In 1000's } & \multirow{2}{*}{$\begin{array}{l}\text { \% Change } \\
2000-2005\end{array}$} \\
\hline & 2000 & 2001 & 2002 & 2003 & 2004 & 2005 & \\
\hline Computer and Information Systems Managers & 228 & 316 & 323 & 347 & 337 & 351 & $53.95 \%$ \\
\hline Network and Computer Systems Administrators & 154 & 185 & 179 & 176 & 190 & 200 & $29.87 \%$ \\
\hline Network Systems and Data Communications Analysts & 305 & 353 & 328 & 359 & 312 & 322 & $5.57 \%$ \\
\hline Database Administrators & 54 & 66 & 84 & 72 & 94 & 89 & $64.81 \%$ \\
\hline Computer Scientists and Systems Analysts & 835 & 734 & 682 & 722 & 700 & 745 & $-10.78 \%$ \\
\hline Computer Programmers & 745 & 689 & 630 & 563 & 564 & 581 & $-22.01 \%$ \\
\hline Computer Software Engineers & 739 & 745 & 715 & 758 & 813 & 832 & $12.58 \%$ \\
\hline Computer Support Specialists & 350 & 355 & 353 & 330 & 325 & 334 & $-4.57 \%$ \\
\hline Total & 3,410 & 3,443 & 3,294 & 3,327 & 3,335 & 3,454 & $1.29 \%$ \\
\hline
\end{tabular}

Figure 1: US Bureau of Labor Statistics Professional IS Employment 2000-2005 [1]

From this summary of the USBLS report, Computer and IS Management positions have increased by $53.59 \%$ since 2000 . For those looking for employment who have a bachelor's degree and some work experience, the US Department of Labor forecasts that Computer and Information Systems Managers and Management Analysts will be among the fastest growing occupations through 2014. For those that have just a Bachelor's degree, the Department of Labor predicts that Computer Systems Analysts and Network and Computer Systems Administrators will be among the fastest growing occupations [2].

Although the outlook for students with MIS degrees is very positive, this does not necessarily mean that those who are considering an MIS career are aware of this prognosis. The general perception of many incoming students is that because of the dot-com bust and the widely reported trend of the outsourcing of computing jobs, the job prospects in these careers are meager [3]. This mistaken outlook could be properly remedied by proper promotion of MIS job prospects.

\subsection{An Identity Crisis}

Another problem that has repeatedly vexed students and employers alike is trying to differentiate between the multitudes of computing-related programs often offered by the same institution. The Association for Computing Machinery (ACM), Association for Information Systems (AIS), Institute of Electrical and Electronics Engineers (IEEE), and Association for Information Technology Professionals (AITP) have identified 5 disciplines resulting in computing-oriented degrees: Computer Engineering, Computer Science, Information Systems, Information Technology, and Software Engineering [4]. The disciplines all have a different focus with diverse career goals. The Computing Curriculum 2005 report describes how each of these disciplines is differentiated:

Computer Engineering programs' primary focus is on the development of the hardware and interfaces to the hardware in computing systems. The CE programs have a heavy emphasis on electrical engineering and mathematical skills

Computer Science programs' primary focus is on the theoretical and algorithmic foundations of software systems and new applications of existing and newly developed hardware. CS programs have a heavy emphasis on mathematics, algorithms, and software engineering.

Information Technology programs' primary focus is on the application of technology to fulfill an organization's needs. IT programs emphasize the utilization of technology components and would typically include installing, customizing, \& maintaining applications, network administration, security, etc.
Software Engineering programs' primary focus is on the development and maintenance of software systems. SE programs have a heavy emphasis on systems design and programming. There are many commonalities between the SE and CS disciplines and often are both handled within CS.

Information Systems programs' primary focus is on the integration of business processes with information technology. IS programs (including MIS and CIS) are handled by business colleges and have a heavy emphasis on organizational principles, management techniques, and business processes [4].

Although all of these programs work with computers and technology, they each have their place and all are required by today's organizations. Each is called upon to fulfill specific roles within an organization.

The National Association of Colleges and Employers (NACE) reports that there are 55 different job categories that are offered to students with degrees related to MIS [5]. There are three primary job categories, though, which MIS programs are generally geared towards preparing students for and which fit the profile outlined by the Computing Curriculum 2005 report: Business Analyst, Systems Analyst, and Information Systems Management. The Department of Labor provides the following descriptions for each of these careers:

Business Analyst: Analyze business or operating procedures to advise most efficient methods of accomplishing work. May install new systems and train personnel in application. May conduct operational effectiveness reviews. May develop or update functional or operating manuals outlining established methods of performing work in accordance with organizational policy. The median salary of business analysts in 2004 was \$63,450. Employment of business analysts is expected to grow faster than the average for all occupations through 2014 [6].

Systems Analyst: Include workers who analyze management and operational problems, and develop business methods and procedures, including accounting systems, file systems, office systems, logistics systems, and production schedules. The median salary of systems analysts in 2004 was \$66,460. Employment of systems analysts is expected to grow much faster than the average for all occupations through 2014 [7]. Although similar in description, the primary differentiation between the Business Analyst (BA) and the Systems Analyst (SA) is that the BA's primary focus is on the business processes and methodologies, while the SA focuses more on the technological aspects of system analysis and how to integrate them into business.

Computer and Information Systems Managers: Computer and information systems managers plan, coordinate, and direct research and facilitate the computer-related activities of firms. They help determine both technical and business goals in consultation with top management and make detailed plans for the accomplishment of these goals. The median salary of IS mangers in 2004 was \$92,520. Employment of computer and information systems managers is expected to grow faster than the average for all occupations through 2014 [8].

Some students avoid the computing-related disciplines because of their notion that they all have strong math and technical requirements. However, the MIS discipline and the careers associated with it primarily focus on the business integration side of information systems. 
Another mistaken assumption regarding MIS careers is that there are few, if any, entry-level management positions available. However, with the tremendous job growth in this venue, organizations are placing more recent college graduates into these positions. Additionally, despite the word "Management" in the job title, many of these positions do not have employees who report directly to them. They often function as intermediaries between the IS departments and the other managers in the organization (the nerd wranglers), manage outsourcing relationships, and work with business units to develop strategy [9].

As with the "jobs crisis," this mistaken outlook can be remedied by proper education of students as to the requirements for studying MIS and the responsibilities of typical MIS graduates.

\subsection{Student Disinterest}

Disinterest in the MIS discipline is another obstacle to overcome. Anecdotal evidence suggests that it should not be a career choice that would drive away students. Through the period of time in which we've observed the precipitous drop in enrollment in MIS programs, other business majors have not exhibited the same decline. This seems to suggest that students are not averse to business-oriented careers. Most students are also quite comfortable working with computers and technology, so apprehension of using computers does not appear to explain the apparent disinterest in the MIS discipline, either.

The only other explanation for this apparent disinterest in the MIS discipline would be related to the mistaken notion that there are few jobs in this area or that students are not familiar with what MIS entails. Overcoming these perceived obstacles will take a significant amount of education and promotion, but may be able to curtail much of the impediments students believe exist in choosing a career in MIS.

\subsection{The Quality Crisis}

One of the remaining potential sources of the significant decline in MIS enrollment has to do with the quality of the programs, themselves. For over two decades, researchers have sought to determine what the skills requirements of organizations are for IS professionals and what skills are lacking in recent graduates of IS programs $[10,11,12,13,14,15,16,17,18,19,20]$. The purpose of this research has been to establish an appropriate fit between what students are taught and what employers need from their MIS professionals. The results of the studies have been fairly consistent in their conclusion that MIS graduates are generally lacking in the quality of the skills that are of the most interest to employers.

In South Korea, the government has gone so far as to direct the University system to develop curriculum requirements based upon industries' needs by applying the concept of supply chain management to human resource development [21]. Although this may be too drastic a measure for Universities within the United States, the method employed in the development of their curriculum is certainly worthy of further investigation as to how it could be applied here.

Most of the previous studies categorize the skills included in their surveys as soft skills and hard skills. Soft skills have been defined as those which are "of a non-technical nature" [16, 18], or the authors would simply supply examples of what soft skills are used in their study. However, without providing an adequate definition for what comprises soft skills and hard skills, these results are somewhat misleading (e.g., some researchers may classify a skill as a soft skill while others may call it a hard skill). The consensus of the prior research is that organizations place a greater emphasis on soft skills (as obtusely as they were defined) than on hard skills.

For the purpose of this paper, soft skills are those which are related to an individual's personality traits, work ethic, interpersonal skills, problem-solving skills, and language skills. Hard skills are those which are specific to a particular task or which produce an immediate visible result. However, given the broad spectrum of skills which can be categorized as hard skills with this definition, we'd like to subcategorize hard skills for MIS graduates as those which are technology-related and those which are non-technology based (e.g., general business skills). This will allow us to focus on further clarifying which skill sets are most important to industry. Hard and soft skills will be specified more completely in the next section.

Starting with Trauth in her 1993 study, much of this research has centered around the "expectation gap" to not only determine what industry needs but also what role academic institutions have in satisfying them [14]. The expectation gap is the difference between what skills industry expects from college graduates and what level of skill they feel the graduates possess.

Another aspect of research which focuses on the expectation gap that is generally lacking is an overall evaluation of the skills to determine which ones are most important to their organization. Although some might assume that a skill that an organization expects their new hires to have would be considered important to the organization, it is not always the case. Employers may want or need a particular skill (e.g. COBOL programming), but not expect that skill from MIS graduates. The other problem with utilizing the expected skills as a proxy for what skills are important to an employer is that the expected skill evaluation is backward-looking and may not provide a clear indication as to which skills will be important to the organization in the future. Consequently, this research will not only seek to determine what the current skills gap is but also what skills employers believe will be important to new hires in these positions in the near future.

One of the deficiencies of the studies previously cited are that they may focus on a particular industry, exclude important industries, or use convenience samples (firms which recruit at a particular university, members of organizations which are regional, etc.). This limits the generalizability of the results of their studies. To make the results more generalizable, the sample needs to include organizations from across a broad spectrum of industry types, size, and locations.

To gauge the potential benefit to the school offering the MIS degree and to the students as a result of a change in curriculum to meet industry's needs, it is also necessary to find some way of measuring the potential likelihood for employers to recruit at and hire from schools which meet these challenges. The Theory of Planned Behavior (TPB) has been applied previously to gauge the intent of an individual to perform some action [22]. One component of the TPB is that the behavioral beliefs relate to the likely outcomes of the action (e.g. hiring employees with a lower skills gap would generally result in better-performing employees). This is moderated, however, by the normative beliefs (including the expectations of others) and control beliefs (presence of factors 
which may facilitate or impede the behavior) [22]. In order for the behavioral beliefs to result in a change in action, they would have to overcome any incongruity in the normative and control beliefs.

\section{THE SKILLS}

After evaluating prior research, industry periodicals and want ads, a list of 32 soft skills, 20 non-technical hard skills, and 43 technical hard skills were identified. Three instructors and a graduate student were asked to rate each of the skills based upon their perceived importance for MIS graduates, the ability to train students in these skills, and determine if there was overlap or omitted items in the skills. After applying an inter-rater mean to the results, the list was pared down to 23 soft skills, 17 general business skills (non-technical hard skills), and 43 technical hard

\begin{tabular}{|c|c|c|c|}
\hline Soft Skills & Business Skills & Technical Skills & Programming Skills \\
\hline Problem-solving skills & Business processes & Software development & Current languages \\
\hline \multirow{8}{*}{$\begin{array}{l}\text { Ability to Learn } \\
\text { Attention to Details } \\
\text { Business Problem Solving } \\
\text { Creativity } \\
\text { Critical thinking } \\
\text { General Problem Solving } \\
\text { Research skills } \\
\text { Working under pressure }\end{array}$} & \multirow{7}{*}{$\begin{array}{l}\text { Accounting } \\
\text { Business Process Design/ } \\
\quad \text { Re-engineering } \\
\text { Contracting and legal } \\
\text { Finance } \\
\text { Marketing } \\
\text { Supply Chain } \\
\quad \text { Management }\end{array}$} & Agile Development & .NET \\
\hline & & CASE Tools & AJAX \\
\hline & & Client-Server & ASP \\
\hline & & Programming & $\mathrm{C} / \mathrm{C}++$ \\
\hline & & SDLC & $\mathrm{C \#}$ \\
\hline & & System Testing & ColdFusion \\
\hline & & Systems Analysis & HTML/XHTML/DHTML \\
\hline & \multirow{4}{*}{$\begin{array}{l}\text { Management skills } \\
\text { Change Management } \\
\text { Managing 3rd party } \\
\text { providers }\end{array}$} & Systems Design & \multirow{2}{*}{$\begin{array}{l}\text { Java/J2EE/J2P } \\
\text { Perl }\end{array}$} \\
\hline Interpersonal skills & & User-Interface Design & \\
\hline \multirow{5}{*}{$\begin{array}{l}\text { Conflict Resolution } \\
\text { Interpersonal Relationships } \\
\text { Leadership } \\
\text { Self-esteem } \\
\text { Teamwork }\end{array}$} & & Web-based Application & \multirow{4}{*}{$\begin{array}{l}\text { PHP } \\
\text { SQL } \\
\text { Visual Basic } \\
\text { XML }\end{array}$} \\
\hline & & Deveropment & \\
\hline & \multirow{5}{*}{$\begin{array}{l}\text { Outsourcing Management } \\
\text { User Relationship } \\
\quad \text { Management } \\
\text { Working Globally } \\
\text { Working with Virtual } \\
\text { Teams }\end{array}$} & Business applications & \\
\hline & & $\begin{array}{l}\text { Appiymg 11 to Business } \\
\text { Problems }\end{array}$ & \\
\hline & & Customer Relationship & \multirow{2}{*}{$\begin{array}{l}\text { Legacy languages } \\
\text { Ada }\end{array}$} \\
\hline \multirow{7}{*}{$\begin{array}{l}\text { Work ethic } \\
\text { Initiative/Motivation to } \\
\quad \text { work } \\
\text { Integrity/Honesty/Ethics } \\
\text { Professional Ethics } \\
\text { Responsibility } \\
\text { Self-management } \\
\text { Time Management }\end{array}$} & & Management (CRM) & \\
\hline & & DSS/GDSS & \multirow{17}{*}{$\begin{array}{l}\text { COBOL } \\
\text { Smalltalk }\end{array}$} \\
\hline & Project management & $\begin{array}{l}\text { Enterprise Resource } \\
\text { Planning (ERP) }\end{array}$ & \\
\hline & $\begin{array}{l}\text { Project Management/ } \\
\text { Planning/Budoeting/ }\end{array}$ & Operating Systems & \\
\hline & Scheduling & Transaction Processing & \\
\hline & Project Risk Management & Whastems & \\
\hline & Strategy skills & Information & \\
\hline \multirow{11}{*}{$\begin{array}{l}\text { Language skills } \\
\text { Negotiation Skills } \\
\text { Oral Communications } \\
\text { Questioning skills } \\
\text { Written Communications }\end{array}$} & Business Intelligence & management & \\
\hline & Business Strategy & Data Mining & \\
\hline & Project Integration & Data Warehousing & \\
\hline & & Database Administration & \\
\hline & & $\begin{array}{l}\text { Electronic Data } \\
\text { Interchange (EDI) } \\
\text { Online Analytical } \\
\text { Processing (OLAP) }\end{array}$ & \\
\hline & & Hardware & \\
\hline & & $\begin{array}{l}\text { Business Continuity } \\
\text { Planning (BCP) }\end{array}$ & \\
\hline & & IT Architecture/Standards & \\
\hline & & Network administration & \\
\hline & & Security & \\
\hline & & Voice/Data Telecom & \\
\hline
\end{tabular}

skills. The technical hard skills were further subcategorized as 16 programming and 27 non-programming technical hard skills.

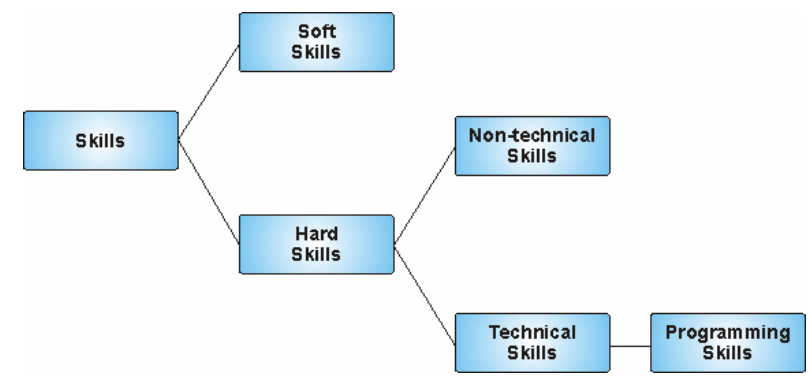

Figure 2: Skills Hierarchy 


\section{RESEARCH QUESTION}

The primary question this research seeks to resolve is: To what extent are employers likely to change which schools they recruit at and hire from because of any perceived skills gap and the relative importance of those skills for recent MIS graduates and is this likelihood to change recruiting practice moderated by the normative and control beliefs of the employers?

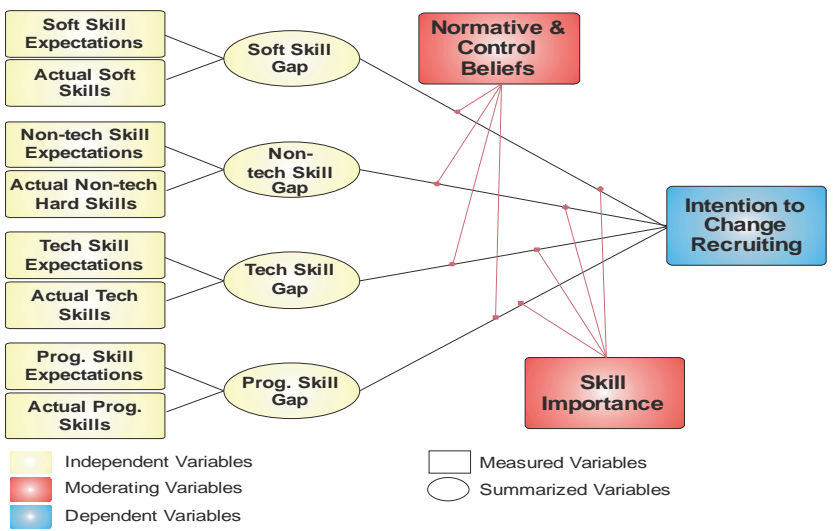

Figure 3: Research Model

\subsection{Variable Definitions}

Skills Gap: Refers to the perceived difference between what the skill expectations are for that skill and the level of skill exhibited by new hires. For each skill, the skills gap will be determined by calculating the difference between the skill expectation and the actual skill as reported by each respondent ("No skills gap” $\bullet$ "Large skills gap"). Within each category of skills (soft skills, business skills, technical skills, and programming skills), the skills gap for that category will be calculated by taking the arithmetic mean of the skills gap for all skills within that category. The skill gap is expected to have a significant and positive impact on the intention to change recruiting for the organization.

Skill Expectations: Refers to the level of competency employers expect of new hires in each of the identified skills. For each of the 82 skills, the respondents will be asked to rate on a 7-point Likert-type scale their response to the following question: What level of this skill does the organization expect new hires with MIS-related degrees to possess ("Expect no skill” $\bullet$ “Expect expert skill”)?

Actual Skills: Refers to the perceived level of skill exhibited by new hires in each of the identified skills. For each of the 82 skills, the respondents will be asked to rate on a 7-point Likert-type scale their response to the following question: What were the actual levels of this skill exhibited by new hires with MIS-related degrees within the past year ("Exhibited no skill” $\bullet$ "Exhibited expert skill” with an additional option of "Unknown”)?

Skill Importance: Is a moderating variable which refers to the perceived importance of each of the skills to the employer. For each of the 82 skills, the respondents will be asked to rate on a 7point Likert-type scale their response to the following question: How important will this skill be for new hires with MIS-related degrees ("Will not be important" $\rightarrow$ "Will be extremely important”)? As the importance of a skill increases where a skills gap has been identified, its impact on the intent to change recruiting practices will increase.

Normative \& Control Beliefs: Is a moderating variable which refers to the TPB model which identifies three aspects of the intent to perform some action. Two of these aspects include the normative beliefs and control beliefs. Based upon prior literature, normative beliefs can include the expectations of others for performing the action and control beliefs can include outside influences or other factors which the decision-maker feels are beyond their control [22]. It is expected that normative and control beliefs will have a moderate and negative impact on the intention to change recruiting practices. To measure the normative and control beliefs, respondents will be asked to rate on a 7-point Likert-type scale their response to the following statements ("Strongly disagree" $\rightarrow$ “Strongly agree”):

- The location of a college or university has a significant influence on whether our organization recruits there.

- Having previously recruited at a college or university has a significant influence on whether our organization recruits there.

- The national reputation of a college or university has a significant influence on whether our organization recruits there.

- Our budget has a significant influence on where our organization recruits.

- Whether an officer in our organization has attended a college or university has a significant influence on whether our organization recruits there.

- We recruit at a particular college or university because our peers also recruit there.

Intention to Change Recruiting Practices: Is the dependent variable and represents the likelihood that an organization will change their current recruiting practices. To determine the organization's intent to change their recruiting practice, we look at past behavior and their perceptions on what their future recruiting behavior will be. The intention to change recruiting practices will be in the range of "Not planning to change" $\leftrightarrow$ "Likely to change". To measure the intent to change recruiting practices, respondents will be asked to rate on a 7-point Likerttype scale their response to the following statements ("Strongly disagree” $\longrightarrow$ “Strongly agree”):

- We have changed which schools we recruit at to fill specific needs in our organization.

- We have changed which schools we recruit at because of the poor preparedness of students for MIS-related positions.

- We are likely to change where we recruit to improve the quality of our MIS new hires' soft skills.

- We are likely to change where we recruit to improve the quality of our MIS new hires’ business skills.

- We are likely to change where we recruit to improve the quality of our MIS new hires' technical skills.

- We are likely to change where we recruit to improve the quality of our MIS new hires’ programming skills. 


\subsection{Hypotheses}

The model in Figure 3 and the rest of the preceding discussion defines the constructs utilized in this research. The expected relationships between each of the constructs in the model are specified in our hypotheses.

To obtain the best possible employees, organizations should seek to hire those individuals who exhibit the skills employers expect them to have. If organizations are experiencing a large gap in the skills of their recent hires, they will be more likely to change where they are recruiting. It is also expected that different classifications of skills (soft skills, business skills, technical skills, and programming skills) will impact the recruitment decision in different ways. Therefore:

HYPOTHESES 1A-D. The skills gap for (a) soft skills, (b) business skills, (c) technical skills, and (d) programming skills will have a significant and positive impact on the intention to change where a firm recruits.

The more important the skills are to the organization, the greater the impact the skills gap will be on the organization's likelihood to change where they are recruiting. However, even if the skills gap is large, if the skill is considered unimportant to the organization it is less likely to impact their decisions on where to recruit. This interaction is represented as the next hypothesis:

Hypothesis 2. The intention to change where the firm recruits will be moderated by the importance of each of the skills. The more important the skill is to the firm, the greater the intent to change where a firm recruits if there is a gap in the skill.

Many facets of the decision regarding where to recruit may not be related to the quality of the employees the organization is seeking to hire. If the need to improve the quality of the new hires is the desired outcome (behavioral beliefs), other factors (according to the TPB) that will have an impact on the intent to change where the organization will recruit include the normative and control beliefs. This relationship is expressed in the following hypothesis:

HyPOTHESIS 3. The intention to change where the firm recruits will be moderated by the normative and control beliefs of the individual responsible for determining the recruitment strategy. As the impact of normative and control beliefs increases, the effect of the skills gap and importance of the skill in the intent to change where a firm recruits will decrease.

Although large firms have the largest IS departments, most people are employed by small and medium businesses (SMB). Consequently, it is important to not only address the needs of large organizations, but understanding the needs of SMBs is also critical. Although large organizations may have larger budgets for implementing a variety of IS applications, SMBs are often on the forefront of innovation. Consequently, we expect there to be little difference in the skills gap of new hires of MIS graduates or the importance of those skills.

HyPOTHESES 4A-B. Firm size will have a nominal effect on the (a) skills gaps and the (b) skill importance.

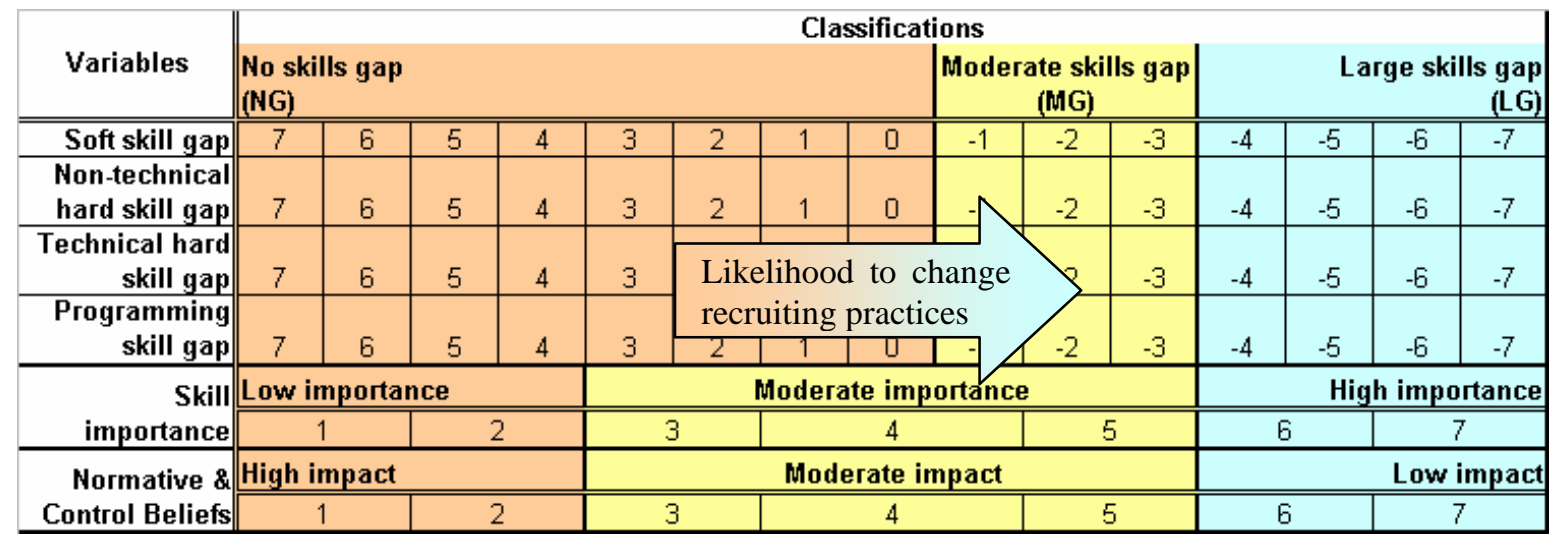

Figure 4: Expected relationships between variables and the intent to change recruiting

\section{METHODOLOGY}

To answer the research question, a survey instrument has been developed which will be sent to the human resource manager of various organizations. Human resource managers were chosen as the preferred respondents to this survey since they are the personnel within an organization who can best assess the skills exhibited during the hiring process of new employees in the organization, can best respond to questions regarding where an organization recruits, and have presumably been given the requirements and skills needs of the organization in order to determine who to hire.

The questionnaire will be administered through a web interface to aid in the rapid completion and return of the survey. Requests to participate in the survey will be delivered to the human resources managers at the Fortune 500 firms to ensure a good representation of large organizations with significant IT departments who are likely to possess the widest variety of skills requirements and have an active recruitment strategy. The request to participate in the survey will also be sent to 500 randomly selected small and medium businesses to gain a representative sample of organizations that have the largest cumulative number of employees.

\section{CONCLUSION}

All data will be collected and analyses completed for presentation at the Conference. It is our belief, that a school which tailors its MIS curriculum to meet the needs of industry will create a competitive advantage for that school whereby firms will actively seek to hire graduates from those programs. Consequently, with proper marketing and promotion of these programs with the likelihood of good job-seeking prospects, MIS enrollment will again rise to at least the levels seen during the dot-com boom days. 


\section{REFERENCES}

[1] Aspray, William, Mayadas, Frank, Vardi, Moshe Y. 2006. Globalization and Offshoring of Software: A Report of the ACM Job Migration Task Force. ACM Job Migration Task Force, 2006.

[2] Bureau of Labor Statistics, U.S. Department of Labor. 2006. Occupational Outlook Handbook, 2006-07 Edition. On the Internet at http://www.bls.gov/oco/pdf/ocotjt1.pdf (visited October 31)

[3] Elbert, D. 2006. Deficit of young IT minds can't fill demand. The Des Moines Register (October 22).

[4] Shackelford, R., McGettrick, A., Sloan, R., Topi, H., Davies, G., Kamali, R., Cross, J., Impagliazzo, J., LeBlanc, R., and Lunt, B. 2006. Computing Curricula 2005: The Overview Report. In Proceedings of the 37th SIGCSE Technical Symposium on Computer Science Education (Houston, Texas, USA, March 03 - 05, 2006). SIGCSE '06. ACM Press, New York, NY, 456-457

[5] JobWeb. 2006. Career Profile Search Results Major/Curriculum: Management Information Systems \& Business Data Processing. On the Internet at http://www.jobweb.com/resources/profileresult.asp?crcode= 10\&list=GO (visited October 31)

[6] Bureau of Labor Statistics, U.S. Department of Labor. 2006. Occupational Outlook Handbook, 2006-07 Edition, Management Analysts. On the Internet at http://www.bls.gov/oco/ocos019.htm (visited May 22)

[7] Bureau of Labor Statistics, U.S. Department of Labor. 2006. Occupational Outlook Handbook, 2006-07 Edition, Computer Systems Analysts. On the Internet at http://www.bls.gov/oco/ocos287.htm (visited May 22)

[8] Bureau of Labor Statistics, U.S. Department of Labor. 2006. Occupational Outlook Handbook, 2006-07 Edition, Computer and Information Systems Managers. On the Internet at http://www.bls.gov/oco/ocos258.htm (visited May 22)

[9] Chabrow, E. 2006. The Manager Boom. Computerworld (October 2)

[10] Cheney, P. H., \& Lyons, N. R. 1980. Information systems skill requirements: A survey. MIS Q, 4, 1 (1980), 35-43.

[11] Cheney, O. H. 1988. Information systems skills requirements: 1980 \& 1988. In Proceedings of the ACM SIGCPR Conference on Management of information Systems Personnel (College park, Maryland, United States, April 07 08, 1988). SIGCPR '88. ACM Press, New York, NY, 1-7.
[12] Watson, H. J., Young, D., Miranda, S., Robichaux, B., and Seerley, R. 1990. Requisite skills for new MIS hires. SIGMIS Database 21, 1 (Sep. 1990), 20-29.

[13] Nelson, R.R. (1991). Educational Needs as Perceived by IS and End-User Personnel: A Survey of Knowledge and Skill Requirements. MIS Q. 15, 4 (1991), 1991, 502-525.

[14] Trauth, E., Fanvell, D., and Lee, D. (1993) The IS Expectation Gap: Industry Expectations Versus Academic Preparation. MIS Q. 15, 3 (1993) 293-307.

[15] Lee, D. M., Trauth, E. M., and Farwell, D. 1995. Critical skills and knowledge requirements of IS professionals: a joint academic/industry investigation. MIS Q. 19, 3 (Sep. 1995), 313-340.

[16] Litecky, C., Prabhakar, B., and Arnett, K. 2006. The IT/IS job market: a longitudinal perspective. In Proceedings of the 2006 ACM SIGMIS CPR Conference on Computer Personnel Research: Forty Four Years of Computer Personnel Research: Achievements, Challenges \&Amp; the Future (Claremont, California, USA, April 13 - 15, 2006). SIGMIS CPR '06. ACM Press, New York, NY, 50-52

[17] Cappel, J. 2002 Entry-level IS job skills: A survey of employers. J. Comput. Inf. Syst. (Winter 2001-2002), 76--82.

[18] Woratschek, C. R. \& Lenox, T. L. 2002. Information Systems Entry-Level Job Skills: A Survey of Employers. Proceedings of the Information Systems Education Conference, San Antonio, TX, 19, 1, 2002.

[19] Gallivan, M. J., Truex, D. P., and Kvasny, L. 2004. Changing patterns in IT skill sets 1988-2003: a content analysis of classified advertising. SIGMIS Database 35, 3 (Aug. 2004), 64-87.

[20] Prabhakar, B., Litecky, C. R., and Arnett, K. 2005. IT skills in a tough job market. Commun. ACM 48, 10 (Oct. 2005), 91-94.

[21] Pak, S., Rho, E., and Chang, J. 2006. Industrial demanddriven curriculums for computer-software field in Korea. In Proceedings of the 11th Annual SIGCSE Conference on innovation and Technology in Computer Science Education (Bologna, Italy, June 26 - 28, 2006). ITICSE '06. ACM Press, New York, NY, 63-67.

[22] Aizen. 2006. Theory of Planned Behavior. On the Internet at http://www.people.umass.edu/aizen/tpb.html (visited May 22) 